special articles

\title{
Reform of psychiatric services in Germany: hospital staffing directive and commissioning of community care
}

The German mental health care system differs significantly from the system in the UK. There is no central organisation with overall responsibility as in the National Health Service (NHS), and the government is not entitled to prescribe details of policy or set specific targets. It can only determine the legal framework, define general goals and, with difficulties, influence the spending level. Responsibilities for mental health care, as for other fields of health care, are shared between federal authorities, the 16 states (Länder), local authorities, and semistatutory organisations, which govern out-patient health care provided by psychiatrists in office-based practices. Virtually every citizen is health-insured and there is free access to health care for those who have no insurance coverage, in which case social services usually cover the costs. Social services also directly fund various services in the community. The fragmented system can be difficult to comprehend. However, many of the challenges are similar to those in other countries, and policy makers and practitioners elsewhere might be interested to know some of the lessons learnt in the German system.

After the second world war, in-patient mental health care was provided in understaffed asylums with low staff morale. Following the murder of people with mental illness by the Nazi regime and the resulting large-scale depopulation of the asylums, patient numbers increased again, although they remained much lower than the UK figures at that time (Häfner, 2001). Asylums were not adequately equipped either for acute treatment or longterm rehabilitative care. In the 1970s, significantly later than in England and the USA, a major reform movement aimed to improve mental health care, and funding for inpatient and out-patient services subsequently increased. The most important milestone was a national enquiry into mental health care, i.e. the Psychiatrie-Enquete (1975). Its recommendations for reforms were endorsed unanimously by the German Bundestag (Bauer et al, 2001) and welcomed by the public and the media (Schmiedebach et al, 2000). They demanded the integration of psychiatric in-patient care into general hospitals and the establishment of in-patient and out-patient services including day services and residential facilities close to where patients live. The Psychiatrie-Enquete initiated a comprehensive reform process replacing custodial care in asylums, with new and much better funded services. Häfner (2001) described this period as a 'humanitarian turning point' in Germany. However, the Psychiatrie-Enquete did not address the structural problems of a highly fragmented health and social care system (DGPPN, 1997; Bundesministerium, 1999; Bauer et al, 2001).

As compared with other Western European countries, Germany has a relatively well-funded health service. More than $10 \%$ of gross domestic product is spent on health care as compared with slightly less than $7 \%$ in England and Wales (Organisation for Economic Cooperation and Development, 2002). The numbers of psychiatrists and of psychiatric beds per population are in the European middle range. Many components of modern mental health care have been widely established. This includes day hospitals, day centres, work rehabilitation services, counselling, residential services of varying intensity and even small multi-disciplinary out-patient services with an outreach function for patients with severe and chronic mental illnesses, which are attached to in-patient units ('Institutsambulanz'). However, there are no community mental health teams, and no agency has overall responsibility for community mental health care in a given catchment area. The principles of community-based care might be endorsed by many mental health professionals, but practice is variable and integration of care remains problematic. There is no substantial barrier between primary and secondary care and patients can directly access psychiatrists in office-based practice and receive specialised treatment whenever they feel the need (Bauer et al, 2001). However, this might be changed in the near future to reduce the costs of the system. Most out-patients are on the case-loads of office-based psychiatrists who are paid on a fee-for-performance basis in a strictly regulated market with a semi-statutory professional organisation exerting stringent control and negotiating fees with health insurance organisations. On average, there is one psychiatrist in office practice per 16300 population. Additionally, there is one psychotherapist with a medical or psychological qualification working in office practice for less than 5000 population.

This paper describes two major initiatives beginning in 1990 and 1997, i.e. the staffing directive for psychiatric hospital services and the guidelines for commissioning community services for chronic mentally ill. The APK (Aktion Psychisch Kranke, i.e. Action Mentally III), a nongovernmental, non-profit organisation was founded in 1971 and is funded by the German Ministry of Health. The organisation works at the interface between mental health professionals and federal policy, and has organised various influential expert commissions including the aforementioned Psychiatrie-Enquete.

\section{The federal directive on staffing of psychiatric hospital services ('Psych-PV')}

In general, psychiatric asylums in Germany were not closed but downsized and better equipped for acute treatment. In addition, further psychiatric in-patient units were established in general district hospitals. The former 
function of asylums in long-term care was transferred to residential and other services in the community. From 1980-2000 the number of psychiatric hospitals, i.e. former asylums, decreased by only 4\% (to 202). However, their size decreased drastically by two-thirds, bringing the bed ratio down to $0.4 / 1000$ population. Within the same period, psychiatric units in general hospitals about doubled their number to 220 with their bed ratio increasing to $0.26 / 1000$. Including old age and addiction services, there are on average 0.66 psychiatric beds per 1000 population with significant regional variation.

The federal staffing directive for in-patient and day care was passed in 1990 (Kunze \& Kaltenbach, 2003). Previous standards for staffing levels in mental hospitals dated back to 1969 and were very low. They applied only to medical and nursing staff and failed to include other professional groups. Staffing indices had been defined as average staff numbers per bed irrespective of the condition and needs of the patients. As a result, hospitals were reluctant to discharge long-stay patients who required little care but, through fixed per-day funding, helped to fund the treatment of the acutely ill.

\section{Aims and methods of the Psych-PV}

The overall aim of the Psych-PV is to improve the quality of hospital treatment by increasing and standardising staffing levels. The plan was to increase spending in steps by a total amount of $€ 271$ million until the year 1995 . The Psych-PV applied to psychiatric hospitals and psychiatric units in general hospitals. The Psych-PV expert group defined a staffing standard independent of the type of institution, its organisational structure, the type of wards and the total number of beds. It suggested that staffing and funding should be dependent on the type of patients in the given service and defined patient groups with similar needs for care. It distinguished three groups of patients in adult psychiatry: general psychiatry; addiction; and old age psychiatric patients. Each of the three main groups was sub-divided into six subgroups according to needs, treatment objectives and treatment methods: routine treatment; intensive treatment; rehabilitative treatment; long-term treatment of the severely ill with comorbid disorders; psychotherapy; and day treatment.

Therefore, 18 staff resource allocation groups have been recommended. In each of these, resource allocation groups packages of care are defined, and time in terms of minutes per week required for each professional group, i.e. psychiatrists, nurses, psychologists, occupational therapists, physiotherapists, social workers, is specified. The standards were arrived at using multiprofessional expert group meetings and bearing in mind a politically set 'ceiling' on budgetary increase. The directive became a binding standard for funding agencies (the health insurers) and hospital management.

\section{The implementation of Psych-PV}

The Psych-PV implementation was audited in 216 out of 401 in-patient psychiatric services. The catchment areas of these services cover $75 \%$ to $80 \%$ of the total population of Germany (Aktion Psychisch Kranke et al, 1998).

The results show that between 1990 and 1995 staffing increased stepwise by a total of $24 \%$ across all professional groups. The number of doctors increased by $43 \%$, nurses by $18 \%$, psychologists by $33 \%$, occupational therapists by $41 \%$ and social workers by $84 \%$. Along with increased staffing, there was an obligation for quality assurance (Kunze, 1998; Kunze \& Priebe, 1998). Between 1990 and 1995 the number of in-patient admissions increased by one-third, whereas the duration of stay decreased by one-third and bed numbers fell by one-fifth. In the period preceding the Psych-PV, the number of beds was reduced from 117000 in 1970 to 86800 in 1988. By 1995, it had declined to 55300 (Old Länder of FRG), a fall roughly equivalent to the previous period (Rössler \& Salize, 1996; Bundesministerium, 1997; Kunze \& Kaltenbach, 2003). However, while psychiatric beds decreased, the number of psychotherapeutic/ psychosomatic beds rose from almost zero in the 1970s to 3200 for treatment and 15400 for rehabilitation in 2001 (Statistisches Bundesamt, 2003). The Psych-PV does not apply to these services, most of which are provided in separate hospitals in rural areas, a costly feature unique to the German mental health care system (2001 data, Statistisches Bundesamt, 2003).

Recently, attempts to cut costs in the German health care system have led to an erosion of the Psych-PV. The principles are still upheld, but in many areas funding and staffing have been reduced. Implementation levels of $90 \%$ or even less are increasingly common.

\section{Guidelines for commissioning of services for people with severe and enduring mental illness in the community}

As in other Western industrialised countries, in Germany during the 1970s and 1980s long-term hospitalised patients, including many with dementia or mental retardation, moved to nursing homes or sheltered living in the community (Kunze, 1985). Currently, the population of people with mental illness in sheltered homes is approximately equivalent to numbers of beds in psychiatric inpatient services (Brill, 2000). There is little empirical evidence on the effects of these changes on the patients concerned (Rössler \& Salize, 1996; Priebe et al, 2002).

\section{The Expert Commission (1992-1996)}

The Federal Ministry of Health asked the APK to build on the concept of the Psych-PV, and improve care planning and staff allocation in community care for patients with chronic mental illnesses (Kauder et al, 1997; Bundesministerium, 1999). The aim was a paradigm shift from 'supply-oriented' to 'needs-led' care. In the fragmented German health care system, a patient living in her or his own accommodation who requires more than usual outpatient treatment can receive the additional support only by moving into an institutional setting. In order to receive different care when needs for support change, the 
(8)

special articles patient has to move to a different institutional setting, which results in discontinuity of therapeutic and social relationships. Many patients tend to stay in a given institutional setting regardless of changing needs. The new person-centred guidelines aim to change this. The commission decided not to define staffing standards for community-based institutions, but to establish patientrelated and goal-oriented staff time budgets, which are to be used in commissioning community mental health care.

The report recommended comprehensive care planning for individual patients including social care, general health care, self-care at home, social contacts, work and education, case management and specific professional interventions. Care plans are to be reviewed at regional case conferences involving all services and funding agencies. Planning includes an estimate of professional time required to deliver care, taking into account resources of the patient and the care system.

\section{Implementation}

Since 2000 pilot projects involving mental health services in 35 catchment areas, covering 10\% of the national population (in different Länder), have tried to implement the guidelines. Pilot projects have specifically involved local authority social services, which fund approximately half of all mental health care. In most areas several organisations, including voluntary and private-for-profit organisations, provide care and often compete with each other for funding. A positive effect of the guidelines has been that different agencies are brought together to discuss what the patient needs rather than what the organisations want to provide. Case conferences have facilitated needs-led and unorthodox funding decisions, and the guidelines appear to have motivated some service providers to adopt a more flexible approach for the care of individual patients. Yet, significant reluctance and rigidity of many provider organisations will have to be overcome if the guidelines are to be successfully implemented across Germany. While the implementation project is funded by the Federal Ministry of Health and some federal states (Länder), there is no funding for evaluative research on its feasibility and effects. This reflects a general shortage of both exact data on service provision and research evaluating the effects of mental health services in Germany.

\section{Conclusions}

More than 10 years after the publication of the federal directive on staffing in in-patient mental health services, it is clear that it has been very beneficial to specify the type of input that should be provided for defined subgroups of in-patients. It has helped to establish staffing levels and secure reasonable funding. The specification of hospital treatment in the Psych-PV has provided commissioners and providers with a rational algorithm for their negotiations. There is good evidence that this has led to a substantial increase in multidisciplinary staff in hospitals and has made a major difference to the quality of in-patient care. However, cost pressures have had a negative impact on the implementation of the Psych-PV. Many psychiatrists are now concerned that the current funding system might be replaced by 'diagnosis-related groups'. This funding system will apply to all hospital services other than in mental health by 2004 , and, if expanded to mental health, might lead to a substantial setback (Fritze, 2003: Kruckenberg, 2003).

The guidelines for commissioning community mental health care have similarities with the care programme approach (CPA) in the UK. On a clinical level, the CPA in the UK is certainly better established, further advanced and probably more effective than the, so far, tentative German approach. The CPA, however, does not need to take direct decisions on funding in a health care system characterised by fragmentation and competition of various public, voluntary and private-for-profit providers. The implementation projects might help to clarify whether and, if so, to what extent, the fragmented system of institutional care in Germany can be overcome so that people with severe and chronic illnesses can 'make the best use of [their] residual capacities in as normal a social context as possible' (Bennett, 1983).

The comparison of the German system of community mental health care with the situation in the UK shows overall higher spending levels and better resourced services in Germany. This spending might have helped to avoid some of the adverse effects of deinstitutionalisation described in other countries (Bachrach, 1997; MunkJørgenson, 1999). Spending levels alone, however, appear not to guarantee an effective organisational structure of care, in particular for patients with severe and chronic mental illnesses. The German experience outlined in this paper also demonstrates that positive reforms can happen in mental health care without top-down prescribed plans on how to deliver services, but that the mechanism of funding arrangements is often a limiting factor. These mechanisms can be more important for how practice develops than scientific evidence or the 'philosophy' of mental health professionals. In conjunction with the economic interest of providers and insurance companies, they appear to make the system more rigid rather than more flexible. By contrast, the public funding through the NHS does not provide financial incentives for individual clinical decisions and certainly has significant benefits, one of which is that there is no need for a complicated and time-consuming decision-making process on funding for every care component.

\section{Acknowledgement}

We thank Professor Jürgen Fritze for his suggestions

\section{Declaration of interest}

Heinrich Kunze is Deputy Chairman (honorary position) of the Aktion Psychisch Kranke Bonn (Action Mentally III), which is funded by the Ministry of Health and Social Security. 


\section{References}

AKTION PSYCHISCH KRANKE, DEUTSCHE

KRANKENHAUSGESELLSCHAFT, SPITZENVERBÄNDE DER

KRANKENKASSEN (eds) (1998)

Bundesweite Erhebung zur Evaluation der Psychiatrie-Personalverordnung.

Schriftenreihe des Bundesministeriums für Gesundheit Band 99. Nomos, Baden-Baden.

BACHRACH, L. (1997) Lesson from the American experience in providing community based services. In Care in the Community - Illusion or Reality? (ed. J. Leff) pp. 21-36. Chichester: Wiley.

BAUER, M., KUNZE, H., VON CRANACH, M., et al (2001) Psychiatric reform in Germany. In Psychiatric Reform in Europe (edsT. Becker, M. Bauer,W. Rutz \& Aktion Psychisch Kranke) pp. 27-34. Acta Psychiatrica Scandinavica, Suppl. No. 410, 104.

BENNETT, D. H. (1983) The historical development of rehabilitation services. In Theory and Practice of Psychiatric Rehabilitation (eds F. N. Watts \& D. H. Bennett) pp. 15-42. Chichester: Wiley.

BRILL, K. E. (2000) Zum Stand komplementärer Angebote. Psychosoziale Umschau, 4, 4-7.

BUNDESMINISTERIUM FÜR JUGEND, FAMILIE, FRAUEN UND GESUNDHEIT (ed) (1988) Empfehlungen der Expertenkommission der

Bundesregierung zur Reform der Versorgung im psychiatrischen und psychotherapeutischen/ psychosomatischen Bereich. Bonn.

BUNDESMINISTERIUM FÜR GESUNDHEIT (ed.) (1997) Daten des Gesundheits wesens - Ausgabe 1997. Schriftenreihe des BMG Band 91. Baden-Baden: Nomos Verlag.
BUNDESMINISTERIUM FÜR GESUNDHEIT (ed) (1999) Von institutions -zu personenzentrierten Hilfen in der psychiatrischen Versorgung. Schriftenreihe des BMG Band 166/ Ambulante KomplexleistungenSozialrechtliche Voraussetzungen zur Realisierung personenzentrierter Hilfen in der psychiatrischen Versorgung. Schriftenreihe des BMG Band 166/II. Baden-Baden: Nomos Verlag.

DGPPN DEUTSCHE GESELLSCHAFT FÜR PSYCHIATRIE UND NERVENHELLKUNDE (1997) Die Behandlung psychischer Erkrankungen in Deutschland -

Positionspapier zur aktuellen Lage und zukünftigen Entwicklung. Berlin Heidelberg: Springer.

FRITZE, J. (2003) Das auf Deutschland angepasste AR-DRG-System als vollpauschalierendes KrankenhausEntgeltsystem. In PsychiatriePersonalverordnung (eds H. Kunze \& L. Kaltenbach)pp. 276-285. Stuttgart: Kohlhammer.

HÄFNER, H. (2001) Die PsychiatrieEnquete - historischeAspekte und Perspektiven. In 25 Jahre PsychiatrieEnquete, Band 1 (ed. Aktion Psychisch Kranke) pp. 72-102. Bonn: PsychiatrieVerlag.

KAUDER V , AKTION PSYCHISCH

KRANKE (1997) Personenzentrierte Hilfen in der psychiatrischen Versorgung. Bonn: Psychiatrie-Verlag.

KRUCKENBERG, P. (2003)

Stellungnahme der Aktion Psychisch Kranke gegen die Einbeziehung der Krankenhauspsychiatrie in das

Diagnose-orientierte Fallpauschalensystem. In PsychiatriePersonalverordnung (eds H. Kunze \& L. Kaltenbach) pp. 271-275. Stuttgart: Kohlhammer.
KUNZE, H. (1985) Rehabilitation and

PRIEBE, S., HOFFMANN, K., ISERMAN, . west Germany. British Journal of Psychiatry, 147, 261-264.

KUNZE, H. (1998) Qualitätssicherung und Personalschlüssel. In

Qualitätssicherung der psychiatrischen Versorgung (eds D. Hell, J. Bengel \& M. Kirsten-Krüger) pp. 72-87. Basel: Karger.

KUNZE, H. \& PRIEBE, S. (1998) Assessing the quality of psychiatric hospital care: a German approach. Psychiatric Services, 49, 794-796.

KUNZE, H. \& KALTENBACH, L. (eds) (2003) Psychiatrie-Personalverordnung (4th edn). Stuttgart: Kohlhammer.

MINISTERIUM FÜR GESUNDHEIT UND SOZIALE SICHERUNG (2003)

Conference of the Health Ministries Bestandsaufnahme zu den

Entwicklungen der Psychiatrie in den letzen.25 Jahren: Bonn.

MUNK-JØRGENSON, P. (1999) Has deinstitutionalisation gone too far? European Archives of Psychiatry and Clinical Neuroscience, 249, $136-143$.

ORGANISATION FOR ECONOMIC COOPERATION AND DEVELOPMENT (2002) OECD Statistical Database. Paris: OECD.
$M$. et al (2002) Do long-term hospitalised patients benefit from discharge into the community? Social Psychiatry and Psychiatric Epidemiology, 37, 387-392

PSYCHIATRIE-ENQUETE - BERICH UBER DIELAGE DER PSYCHIATRIE INDER BUNDESREPUBLIK DEUTSCHLAND (1975) Bundestagsdrucksache 7/4200. Bonn.

RÖSSLER, W. \& SALIZE, J. (1996) Die psychiatrische Versorgung chronisch psychisch Kranker. Daten, Fakten, Analysen. Schriftenreihe des Bundesministeriums für Gesundheit Band 77. Baden-Baden: Nomos.

SCHMIEDEBACH, H.-P., BEDDIES, T., SCHULZ, M., et al (2000) Open care RodewischTheses - PsychiatryEnquete: Comparison of three reform approaches. Psychiatrische Praxis, 27 138-143.

STATISTISCHES BUNDESAMT (2003) Gesundheitswesen - Grunddaten der Krankenhäuser und Vorsorge oder Rehabilitationseinrichtungen. Fachserie 12/Reihe 6.12001. Metzler Poeschel.
*Heinrich Kunze Medical Director, Klinik für Psychiatrie und Psychotherapie Merxhausen, D-34306-Bad Emstal/Kassel, Germany. E-mail: heinrich.kunze@ zsp-kurhessen.de, Thomas Becker Professor of Psychiatry, Department of Psychiatry II, University of Ulm, Günzburg, Germany, Stefan Priebe Professor for Social and Community Psychiatry, Queen Mary's, University of London, Newham Centre of Mental Health, London E13 8SP. 